\title{
Validating student satisfaction with a blended learning scheme in Universitas Terbuka setting
}

\author{
Maximus Gorky Sembiring \\ Faculty of Education and Teacher Training, \\ Universitas Terbuka, \\ Jalan Cabe Raya Pondok Cabe, \\ Pamulang Tangerang Selatan, Indonesia \\ Email: gorky@ecampus.ut.ac.id \\ Email: gorkysembiring@gmail.com
}

\begin{abstract}
Blended learning scheme of Universitas Terbuka was explored here. It was aimed at validating on how, in what routines independent, moderating and dependent variables involved were interrelated. Exploratory design was utilised as part of mixed method. It was qualitatively established first that blended learning satisfaction reflected by instruction, interactivity, instructor, management, technology and OER-wise. Satisfaction led to student learning, competence, motivation, retention and value. It was quantitatively hypothesised that satisfaction was influenced by independent and it had corollary to the dependent variables. This configuration was completed through reviews and focus-group discussions prior to performing survey. Importantperformance analysis (IPA) and customer-satisfaction index (CSI) were utilised to measure satisfaction and importance degree. Eleven hypotheses were assessed using structural-equation model (SEM); nine were validated. Management was the most influential factor, followed by interactivity, instructor, and instruction; excluding OER-wise and technology. Retention was influenced by satisfaction, followed by enhance learning, value, motivation and competence.
\end{abstract}

Keywords: blended learning; exploratory design; IPA; CSI; SEM.

Reference to this paper should be made as follows: Sembiring, M.G. (2018)

'Validating student satisfaction with a blended learning scheme in Universitas Terbuka setting', Int. J. Mobile Learning and Organisation, Vol. 12, No. 4, pp.394-413.

Biographical notes: Maximus Gorky Sembiring is a Senior Lecturer at the Faculty of Education and Teacher Training of Universitas Terbuka. His research mainly focuses on student support systems for open distance learners. $\mathrm{He}$ is currently the Director of Research Center of the University.

This paper is a revised and expanded version of a paper entitled 'Validating Student Satisfaction with a Blended Learning Scheme in Universitas Terbuka' presented at the '2017 International Conference on Open and Innovative Education (ICOIE 2017)', The Open University of Hong Kong, Hong Kong, 12-14 July 2017. 


\section{Introduction}

This report intensifies preceding reviews on comparable designs with an alteration in the operational framework and respondent as compared to the previous studies reported by Ibrahim et al. (2016) and Aisyah et al. (2016). In these two reports, the respondents were graduates and students of Basic Education Program of Universitas Terbuka respectively; here, OER-wise factor was not included. These studies were related to one of essential problems faced by most higher education institutions (HEIs) in delving an adoption of learning atmosphere to simultaneously anticipate and accommodate student necessities and expectation in the digital age. This becomes indispensable as the growing number of student registration and program expansion by many universities worldwide (Poon, 2013a). This trend was not solely related to the conventional universities but it is also relevant to an open distance e-learning (ODeL) ambiance. Each HEI, primarily for ODeL institution, must be able to follow an approach of providing quality education creatively in spite of potential restrictions in terms of delivery, time and space constraints since it should satisfy student need and expectation.

Analysing student demographics for illustration, according to Bates (2015, p.322), may help to decide whether or not the course and/or program should either be delivered face to face or fully online; or even a mixture of them. This is important, since regardless of what form of distance education is being designed, an element that have to be kept in mind for all designers is the extent of student involvement and how to engineer it to be in place and effective primarily viewed from student attitude. This implies that this report focused on how the blended learning is investigated with respect to student satisfaction and at the same time also viewed by students.

Orientation dealing with any hindrance in providing quality education in this context is referred to as the so-called blended learning scheme. As it was identified by Garisson and Kanuka (2004), blended learning is consistent with the values of traditional higher education institutions and has proven potential to enhance not only the effectiveness but also efficiency of meaningful learning experiences. It was recognised as the combination of traditional face to face and mediated online delivery system that aims at complementing one and the other. In Universitas Terbuka context, blended learning scheme has been in function for more than twenty years. This scheme has been fully practiced in the Faculty of Education and Teacher Training, especially in Basic Education Programs, and in the Graduate Programs. Blended learning is the convergence of face to face setting characterised by synchronous features with human interaction that are asynchronous with information communication technology (ICT) measures; mostly text-base and involving human operation independently. Vital to be kept in mind that most interaction between learners and tutors as well as learners to other learners in an online configuration takes the form of asynchronous interaction as that meets the needs of students for convenient in any place or any time for study.

Up to date, this is the third study on blended learning in satisfaction issues using exploratory design following Ibrahim et al. (2016) and Aisyah et al. (2016). Both reports had similar upshots, namely blended learning in Universitas Terbuka ambiance and had been implemented as well as fulfilled user needs. On the other hands, the University blended learning scheme leads to student performance, motivation and retention. Technologically, the scheme involved printed, digitised with audio/video and computer mediated learning materials supports as well as face to face and online tutorial activities. 
To date, more than 120,000 and 2000 students in the Basic Education and the Graduate Programs respectively are engaged in this mode of learning in Universitas Terbuka setting (Universitas Terbuka, 2016). Here, students are equipped with printed and digitised learning materials. Besides, students are provided regular based and scheduled face to face with online tutorial supports. Students are also authorised to gain access to digital library and other related academic portals to support their study; they are all ICT-based. Blended learning is therefore vital not only for the University but most importantly for the students. This is an effort to avoid high attrition rate as through this scheme student involvement is not solely on a voluntary bases anymore. Reasons for using this approach, according to Kenney and Newcombe (2011), as a mixture method, was to enhance student participation, preparation, and understanding as well as to nurture a more active rather than a passive approach to learning that might be particularly difficult in large-sized in most undergraduate courses. Most results documented that the adoption of process gave positive impact through this approach. It showed that the issues and barriers actually encountered when implementing a new instructional strategy is certainly helping faculty when there is a limited funding, training, and other available supports.

This study therefore mainly aims at exploring and assessing blended learning experience in Universitas Terbuka framework. Besides, it was also of interest to validate on how and in what routines all factors involved were interrelated one another. It is expressed by asking the following queries: (1) What are the current blended learning trends; in the view of student under scholarship scheme in Universitas Terbuka? (2) How such experiences might support their study or program? (3) What are the reflections and lesson learnt to improve current scheme with specific view given by students to the faculty as the management? These questions incorporated elaborative impact on pedagogical and technological response collectively. The first and second questions are to identify the position of the existing blended learning scheme. The answer to the third question is to improve satisfaction level for the sake of student success in the near future.

It was finally expected that through this scheme there will be an enhancement aspect on pedagogy, access to knowledge, social interaction, presence of the lecturer, cost effectiveness and ease of revision as it was outlined by Osguthorpe and Graham (2013). By keeping this understanding, it is expected one reality that is seldom talked about but something needs to be kept in mind is that most adult distance learners feel natural fear of failure might then gradually be anticipated (Moore and Kearsly, 2012, p.152) and also cautiously handled viewed from institutional angle by the management of the University.

\section{The conceptual framework}

Conceptually, the study is justified by the following main framework as illustrated in Figure 1.

University policy on the provision of blended learning scheme is derived from general ODeL framework. The study is determined by qualitative approach first and then followed by quantitative series. This is done through the sets of literature reviews and focus-group discussions (FGDs) for qualitative purposes. These sessions are implemented with the help of an exploratory design approach as part of mixed methods. Quantitatively, blended learning dimensions and attributes are then evaluated simultaneously under customer-satisfaction index (CSI) and important-performance analysis (IPA) approach 
first and then followed by structural-equation model (SEM) technique to examine the hypotheses and the loading factors of the operational framework afterwards.

Figure 1 The conceptual framework

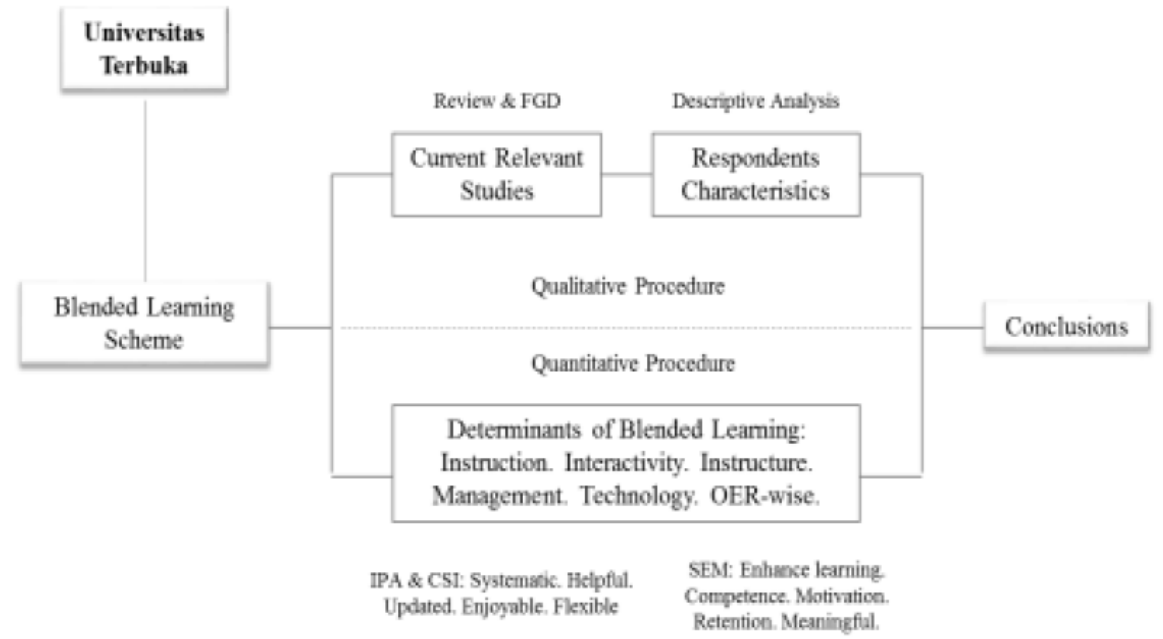

Based on the qualitative procedure, following the first part of the process as shown in Figure 1, it can conceptually be summarised several variables and dimensions engaged in this study as shown in Table 1 resulted from related literature reviews (Bates, 2015; Moore and Kearsly, 2012) and FGDs by involving selected experienced and reputable academic from the management of the University.

Table 1 Summary of variables and dimensions engaged

\begin{tabular}{|c|c|c|c|}
\hline No & Variables & Dimensions & Remarks \\
\hline \multirow{3}{*}{1} & \multirow{3}{*}{ Instruction $\mathbf{X}_{1}$} & $\mathrm{X}_{11}:$ More independent & \multirow{6}{*}{$\begin{array}{l}\mathrm{X}_{1-6}, \mathrm{~S} \text { and } \mathrm{Y}_{1-5} \text { were independent, } \\
\text { moderating and dependent } \\
\text { variables successively }\end{array}$} \\
\hline & & $\mathrm{X}_{12}$ : Comprehensive & \\
\hline & & $\mathrm{X}_{13}$ : Ready for examination & \\
\hline \multirow{3}{*}{2} & \multirow{3}{*}{ Interactivity $\mathbf{X}_{2}$} & $\mathrm{X}_{21}:$ Focus or alert & \\
\hline & & $\mathrm{X}_{22}$ : Multi-way direction & \\
\hline & & $\mathrm{X}_{23}$ : Promote response & \\
\hline \multirow{3}{*}{3} & \multirow{3}{*}{ Instructor $\mathbf{X}_{\mathbf{3}}$} & $\mathrm{X}_{31}$ : Available & \multirow{6}{*}{$\begin{array}{l}\text { Each independent variable }(\mathbf{X}) \text { has } \\
3 \text { dimensions and } 3 \text { questions for } \\
\text { each dimension }\end{array}$} \\
\hline & & $\mathrm{X}_{32}$ : Encouraging & \\
\hline & & $\mathrm{X}_{33}:$ Open mind & \\
\hline \multirow{3}{*}{4} & \multirow{3}{*}{ Management $\mathbf{X}_{4}$} & $\mathrm{X}_{41}$ : Discipline & \\
\hline & & $\mathrm{X}_{42}$ : Fully attentive & \\
\hline & & $\mathrm{X}_{43}$ : Consistent in implementation & \\
\hline \multirow{3}{*}{5} & \multirow{3}{*}{ Technology $\mathbf{X}_{\mathbf{5}}$} & $\mathrm{X}_{51}$ : Affordable by student & \multirow{3}{*}{$\begin{array}{l}\text { These questions should be } \\
\text { answered } 2 \text { times concurrently } \\
\text { by the respondents }\end{array}$} \\
\hline & & $\mathrm{X}_{52}$ : Reliable in every condition & \\
\hline & & $\mathrm{X}_{53}$ : Friendly for any user & \\
\hline
\end{tabular}


Table 1 Summary of variables and dimensions engaged (continued)

\begin{tabular}{|c|c|c|c|}
\hline No & Variables & Dimensions & Remarks \\
\hline \multirow{3}{*}{6} & \multirow{3}{*}{ OER-wise $\mathbf{X}_{6}$} & $\mathrm{X}_{61}$ : Relevance & \multirow{8}{*}{$\begin{array}{l}\text { The first part of each question } \\
\text { measured the satisfaction level and } \\
\text { - the second part measured its } \\
\text { importance degree }\end{array}$} \\
\hline & & $\mathrm{X}_{62}$ : Interactive & \\
\hline & & $\mathrm{X}_{63}:$ Sufficient & \\
\hline \multirow{5}{*}{7} & \multirow{5}{*}{$\begin{array}{l}\text { Blended } \\
\text { Learning } \\
\text { Satisfaction } \mathbf{S}\end{array}$} & $\mathrm{S}_{1}$ : Systematic & \\
\hline & & $\mathrm{S}_{2}:$ Helpful & \\
\hline & & $\mathrm{S}_{3}$ : Updated & \\
\hline & & $\mathrm{S}_{4}$ : Enjoyable & \\
\hline & & $\mathrm{S}_{5}$ : Flexible & \\
\hline \multirow{2}{*}{8} & \multirow{2}{*}{$\begin{array}{l}\text { Enhance } \\
\text { Learning } \mathbf{Y}_{\mathbf{1}}\end{array}$} & $\mathrm{Y}_{11}$ : Supplementary learning & \multirow[t]{2}{*}{$\mathrm{S}$ was influenced by $\mathrm{X}_{1-6}$} \\
\hline & & $\mathrm{Y}_{12}$ : Reinforce learning skill & \\
\hline \multirow{2}{*}{9} & \multirow{2}{*}{ Competence $\mathbf{Y}_{2}$} & $\mathrm{Y}_{21}$ : Conceptual knowledge & \multirow{2}{*}{$\begin{array}{l}\text { Other variables }\left(\mathrm{Y}_{1-5}\right) \text { were } \\
\text { controlled by satisfaction }(\mathrm{S})\end{array}$} \\
\hline & & $\mathrm{Y}_{22}:$ Applied skill & \\
\hline \multirow{2}{*}{10} & \multirow{2}{*}{ Motivation $\mathbf{Y}_{\mathbf{3}}$} & $\mathrm{Y}_{31}:$ Inquisitive & \multirow{4}{*}{$\begin{array}{l}\text { Questions on these } \\
\text { variables }\left(\mathrm{Y}_{1-5}\right) \\
\text { answered only ones }\end{array}$} \\
\hline & & $\mathrm{Y}_{32}:$ Enthusiastic & \\
\hline \multirow{2}{*}{11} & \multirow{2}{*}{ Retention $\mathbf{Y}_{\mathbf{4}}$} & $\mathrm{Y}_{41}$ : Explicable & \\
\hline & & $\mathrm{Y}_{42}:$ Memorable & \\
\hline \multirow{2}{*}{12} & \multirow{2}{*}{ Valuable $\mathbf{Y}_{\mathbf{5}}$} & $\mathrm{Y}_{51}:$ In line with everyday life & \\
\hline & & $\mathrm{Y}_{52}:$ Beneficial for daily work & \\
\hline
\end{tabular}

In this stage, there is a new additional variable introduced, namely OER-wise, to be included as one of the main variable influencing blended learning satisfaction. Consideration of including this additional variable referring to the characteristics of relatively easy to re-use and re-distribute. Moreover, it is also effortless to revise, remix and retain (Bates, 2015, p.345). The OER-wise, as inspired by Kanwar et al. (2010), is therefore included as the sixth independent variable on this study in addition to what was previously completed by Ibrahim et al. (2016) and Aisyah et al. (2016). Aligned with the related literatures study have been conducted, another qualitative approach was used to form the basic elements of the conceptual framework by conducting FGDs and interviews with assigned five experts from the University as well as selected six active students resided in four out of 38 eight different regional centres.

\section{Design and the methodology}

Methodologically, satisfaction (S) in blended learning is the moderating variable. It will quantitatively be observed through the six stand points (the independent variables). They are: instruction, interactivity, instructor, management, technology (Naaj et al., 2012) and OER-wise (Sembiring, 2016). These six variables are observed with respect to how systematic, helpful, updated, enjoyable and flexible are the blended learning scheme 
provided, used and experienced by students. Each independent variable is perceived upon three attributes. Independent variables with the three attributes of each dimension are used to observe satisfaction level and its importance degree. It will be then observed whether or not satisfaction has effects on the student learning, competence, motivation, retention and value (inspired by Smaldino et al., 2008); these are the dependent variables. The operational framework will be developed and then assessed elaborated from the summary of variables and dimensions involved as exhibited in Table 1.

The study utilises mixed methods that is the exploratory design (Creswell and Clark, 2011). The study is implemented under qualitative approach first and then followed by quantitative sequence. Two types of instruments were developed, they are list of queries for literature reviews, interviews and FGDs (for qualitative necessities) and the set of questionnaire (for quantitative purpose). Table 1 is a basis of developing instruments in the form of questionnaire. All questions incorporated in $\mathrm{X}\left(\mathrm{X}_{11}-\mathrm{X}_{63}\right)$ were simultaneously answered two times by the respondents (Table 1). The first and second answers measured satisfaction level and their importance degree respectively. The rests are answered once by respondents to view the effects of satisfaction with respect to student learning, competence, motivation, retention and value as the dependent variables.

Aligned with the related literatures review conducted prior to the quantitative series, another qualitative approach was used to form basic elements of the conceptual framework by conducting FGD and interview with assigned five experts from the University as well as selected six active students reside in four different regional centres. Experts and students, as resource persons, were mainly asked four major questions and categorised as: (1) Main variables of blended learning scheme as moderating variable related to satisfaction, (2) Dimensions attached to each variable involved, (3) The impact of satisfaction to student need and expectation, and (4) Their view on blended learning scheme conducted by the University.

Variables and dimensions engaged are explored through questionnaire as inspired by Bird (2009). Survey is implemented to gather related data and relevant information from respondents by following Fowler (2014). Population of the study is 5500 (out of 290,000 in total) students from three faculties (Faculty of Economics, Faculty of Mathematics and Natural Sciences and Faculty of Law, Social and Political Science) under scholarship program. Purposive sampling (for qualitative) and simple random sampling (for quantitative) techniques are selected to choose eligible respondents (Cochran, 1977). For the survey itself, 600 questionnaires (see Appendix: The Questionnaire) were distributed and 296 of them were finally completed. IPA and CSI are then simultaneously utilised to assess satisfaction level concerning blended learning scheme along with its importance degree (Kitcharoen, 2004; Silva and Fernandes, 2010; Wong et al., 2011). SEM is finally applied to discover conceivable interactions amongst factors engaged by practicing Wijayanto (2008) and Hair et al. (2009). The overall operational framework is established by reflecting the summary in Table 1. It is a reflection of how they are related one another, including the hypotheses analysis. They are all systematically illustrated in Figure 2.

Figure 2 illustrates features affecting satisfaction (S) leading to student: learning $\left(\mathrm{Y}_{1}\right)$, competence $\left(\mathrm{Y}_{2}\right)$, motivation $\left(\mathrm{Y}_{3}\right)$, retention $\left(\mathrm{Y}_{4}\right)$ and value $\left(\mathrm{Y}_{5}\right)$. Satisfaction includes features in terms of systematic $\left(\mathrm{S}_{1}\right)$, helpful $\left(\mathrm{S}_{2}\right)$, updated $\left(\mathrm{S}_{3}\right)$, enjoyable $\left(\mathrm{S}_{4}\right)$ and flexible 
$\left(\mathrm{S}_{5}\right)$ perspectives. Satisfaction is assessed by perceiving attributes from dimensions of instruction $\left(\mathrm{X}_{1}\right)$, interactivity $\left(\mathrm{X}_{2}\right)$, instructor $\left(\mathrm{X}_{3}\right)$, management $\left(\mathrm{X}_{4}\right)$, technology $\left(\mathrm{X}_{5}\right)$ and OER-wise $\left(\mathrm{X}_{6}\right)$ configurations. The instrument consists of $2 \times 23$ questions related to the satisfaction degree and the level of its importance; and other 11 questions are to validate whether or not the dependent variables $\left(\mathrm{Y}_{1}-\mathrm{Y}_{5}\right)$ were relatable to satisfaction as the moderating variable. Serially, these results will subsequently be unified with the results obtained from earlier qualitative approach. At the end, it will be confronted with student views to see whether they have the same, different or conflicting upshots one another.

Figure 2 The operational framework

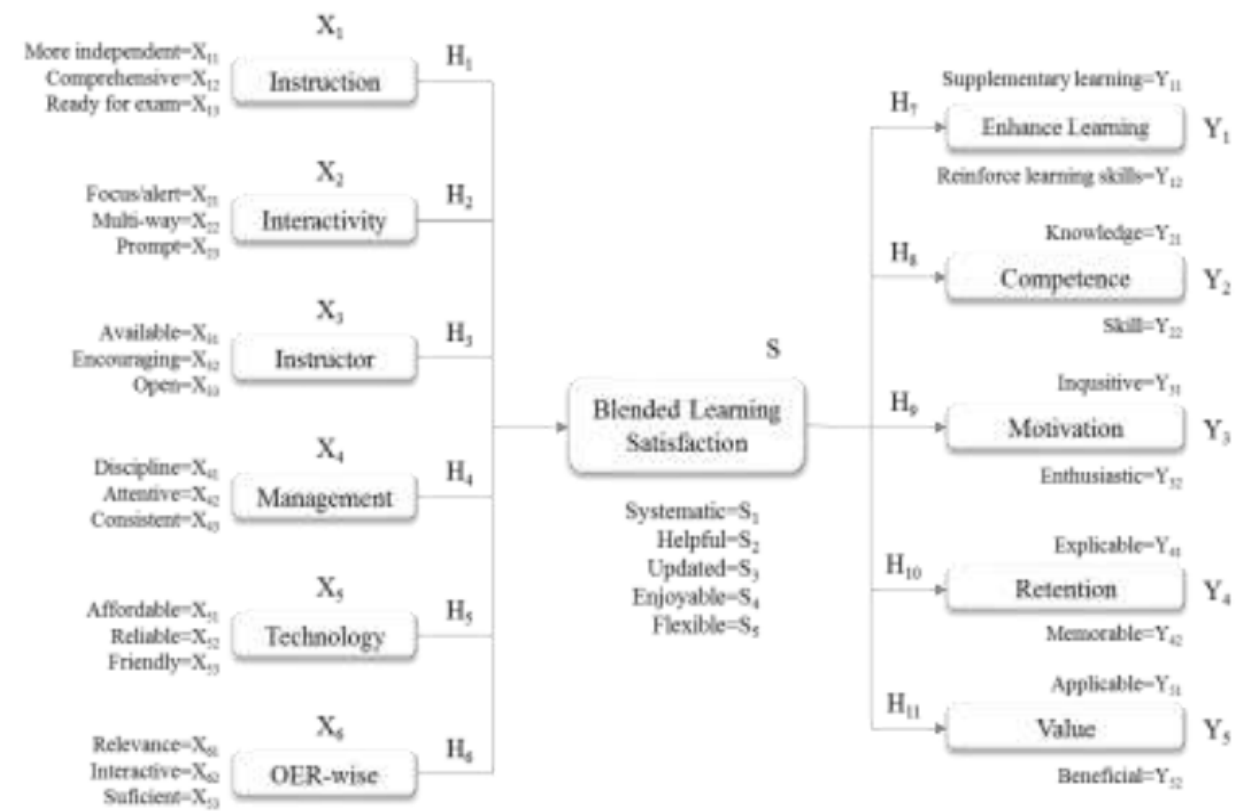

Statistically, this study examines 11 hypotheses $\left(\mathrm{H}_{1-11}\right.$, Figure 2$)$. Satisfaction with blended learning $(\mathrm{S})$ is directly influenced by instruction $\left(\mathrm{H}_{1}\right)$, interactivity $\left(\mathrm{H}_{2}\right)$, instructor $\left(\mathrm{H}_{3}\right)$, management $\left(\mathrm{H}_{4}\right)$, technology $\left(\mathrm{H}_{5}\right)$ and OER-wise $\left(\mathrm{H}_{6}\right)$. Additionally, student learning $\left(\mathrm{H}_{7}\right)$, competence $\left(\mathrm{H}_{8}\right)$, motivation $\left(\mathrm{H}_{9}\right)$, retention $\left(\mathrm{H}_{10}\right)$, value $\left(\mathrm{H}_{11}\right)$ are directly influenced by satisfaction $(\mathrm{S})$.

\section{Results and discussions}

Having described all related fundamentals, we are now in the position of revealing the results of hypotheses and later the loading factors including goodness of fit of the tested framework by considering all related facts as shown in Figure 3. 
Figure 3 Hypotheses and loading factor results

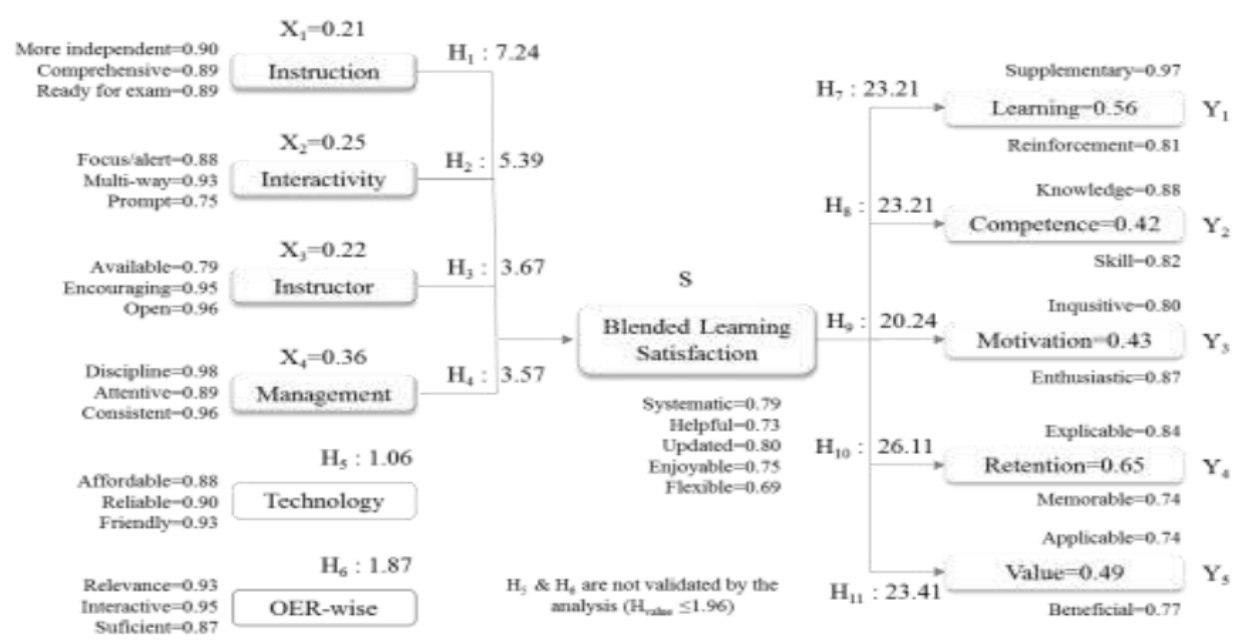

\section{Hypotheses analysis}

Figure 3 evidently shows that nine hypotheses were positively validated by the analysis They are: $\mathrm{H}_{1}=7.24$ (instruction to satisfaction), $\mathrm{H}_{2}=5.39$ (interactivity to satisfaction), $\mathrm{H}_{3}=3.67$ (instructor to satisfaction), $\mathrm{H}_{4}=3.57$ (satisfaction to competence). Moreover, $\mathrm{H}_{7}=23.21$ (satisfaction to learning), $\mathrm{H}_{8}=23.21$ (satisfaction to competence), $\mathrm{H}_{9}=20.24$ (satisfaction to motivation), $\mathrm{H}_{10}=26.11$ (satisfaction to retention) and $\mathrm{H}_{11}=23.41$ (satisfaction to value), as the $t_{\text {values }}>1.96$ (for $\alpha=0.05$ ). While $\mathrm{H}_{5}=1.06$ (technology to satisfaction) and $\mathrm{H}_{6}=1.87$ (OER-wise to satisfaction) were not validated by the analysis, as the $t_{\text {values }}<1.96$ (for $\alpha=0.05$ ).

Looking at to the first two of invalidated hypothesis $\left(\mathrm{H}_{5}\right)$, it is crucial to see further later whether or not it was due to the lack of access to computers and the Internet, the lack of infrastructure, low levels of computer literacy, the lack of local language content or the lack of other formal support services available as major barriers to implementing compulsory online activities (Liyanagunawardena et al., 2014). Similarly, it is also good to review what is the reason and why OER-wise $\left(\mathrm{H}_{6}\right)$ is not included as one of the main independent variable of the quantitative framework in this study. OER clearly offers a crucial prospect to enhance the quality of education and facilitate dialog and knowledge sharing. It is an actual resource that may enrich classroom environment and encourage student thinking and comprehension. Moreover, a fundamental concept of OER is the ability to freely adapt and reuse existing piece of knowledge. It is the way to create more economic and personalised learning. OER movement has challenged the traditional value chain by employing new methods to deliver quality educational content. OER is therefore expected to play a decisive and productive role for and in blended learning scheme; these two critical notes need to be cautiously noted suppose comparable study will be conducted in the near future.

\section{Respondents characteristics}

Now, to have a more comprehensive view toward the end result, it would be better to reveal the characteristics of respondents of the study first (Table 2). This will give better perception to comprehend the discussions before exposing the final outcomes. 
Table 2 Respondents characteristics

\begin{tabular}{c|cccc}
\hline Faculty $\%$ & Mathematics $=45.03$ & Economics $=33.77$ & \multicolumn{2}{c}{ Social \& Political Science $=21.20$} \\
\hline \multirow{2}{*}{$\begin{array}{c}\text { Regional Office } \\
38 \text { (of 40) }\end{array}$} & $\begin{array}{c}\text { Sumatera } \\
{[10]=10}\end{array}$ & $\begin{array}{c}\text { Java-Bali-Bali } \\
{[13]=13}\end{array}$ & $\begin{array}{c}\text { Kalimantan } \\
{[5]=4}\end{array}$ & $\begin{array}{c}\text { Sulawesi } \\
{[5]=5}\end{array}$ \\
& $\begin{array}{c}\text { Papua } \\
{[2]=2}\end{array}$ & $\begin{array}{c}\text { Nusa Tenggara } \\
{[2]=2}\end{array}$ & $\begin{array}{c}\text { Maluku } \\
{[2]=2}\end{array}$ & $\begin{array}{c}\text { Overseas } \\
{[1]=0}\end{array}$ \\
\hline & $0,00-0,99=0.06$ & $1,00-1,49=012$ & $1,50-1,99=0.56$ & $2,00-2,49=15.18$ \\
GPA (2016) \% & $2,50-2,99=29.74$ & $3,00-3,49=20.25$ & $\begin{array}{c}3,50-3,99 \\
=20.88\end{array}$ & $4,00=0.63$ \\
\hline Age \% (year) & $<20=42.16$ & $21-23=43.37$ & $24-26=14.45$ & $>27=0.00$ \\
\hline $\begin{array}{c}\text { Year of Study } \\
\%\end{array}$ & $<2=14.37$ & $3=16.25$ & $4=69.37$ & $>5=0.06$ \\
\hline $\begin{array}{c}\text { Marital Status } \\
\%\end{array}$ & $\begin{array}{c}\text { Yes }=11.79 \\
\text { No=84.21 }\end{array}$ & If Yes, Children $(\%)$ & $\begin{array}{c}\text { Yes }=16.17 \\
\text { No }=83.83\end{array}$ & \\
\hline $\begin{array}{c}\text { Employment } \% \\
\text { Gender } \%\end{array}$ & Full time $=64.28$ & Part time=11.31 & None $=24.41$ & \\
\cline { 2 - 3 } & Female $=75.59$ & Male=24.21 & & \\
\hline
\end{tabular}

Table 2 essentially reveals that the respondents are categorised as full time students, young, energetic and highly motivated. Moreover, they come from three different faculties with good grade point average as well as representing 38 out of existing 40 regional offices throughout the country; and three forth of them are female. They are generally well-involved with ICT development as the main tool of accessing and utilising the scheme productively.

Having disclosed the hypotheses testing and respondents characteristics, it is right to show the findings from IPA-CSI Chart first and then followed by the loading factors analysis of the operational (quantitative) framework.

The IPA-CSI analysis

The IPA-CSI analysis is meant to expose satisfaction level and their importance degree based on student responses. The analysis generates spots of satisfaction level in conjunction with the related quadrants $(\mathrm{Q})$ to comprehend their importance degree (Figure 4).

Figure 4 The IPA-CSI chart

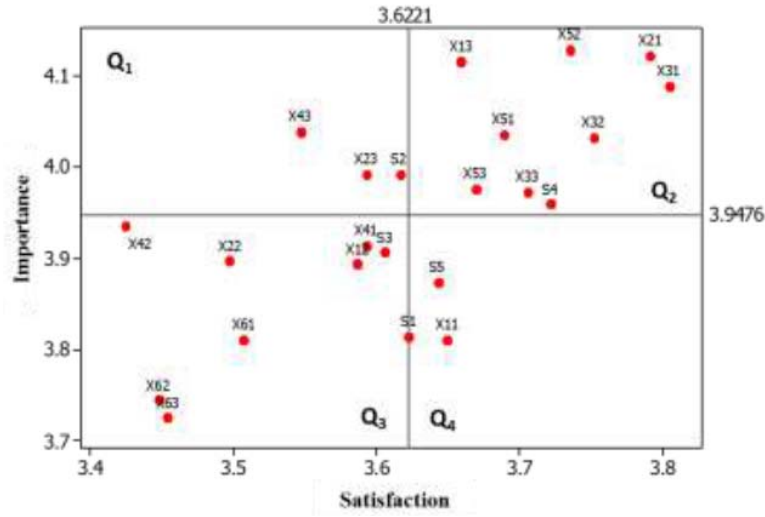


Figure 4 has four Qs, they are: $\mathrm{Q}_{1}$ (Concentrate Here), $\mathrm{Q}_{2}$ (Maintain Performance), $\mathrm{Q}_{3}$ (Low Priority) and $\mathrm{Q}_{4}$ (Possible Overkill); following Wong et al. (2011).

$\mathrm{Q}_{1}$ factually has three critical attributes that should be noted cautiously: $\mathrm{X}_{43}$ (management consistency), $\mathrm{X}_{23}$ (prompt interactivity) and $\mathrm{S}_{2}$ (quick response to help student doubt). $\mathrm{Q}_{1}$ indicates that the satisfaction is at a low level while the degree of its importance is high. The University must be attentiveness to these three marks and put them into a highest priority so student expectation can be fulfilled and they are more likely to get more advantage of the scheme.

$\mathrm{Q}_{2}$ includes nine optimistic attributes that should also be maintained purposefully: $\mathrm{S}_{4}$ (enjoyable), $\mathrm{X}_{33}$ (instructor openness), $\mathrm{X}_{53}$ (friendly), $\mathrm{X}_{51}$ (affordable), $\mathrm{X}_{32}$ (encouraging) and $X_{13}$ (ready for exam), $X_{52}$ (reliable), $X_{21}$ (focus), and $X_{31}$ (available). This quadrant is a sign of both satisfaction and importance degrees are being placed at a high level. The University therefore must take care of these nine positive aspects since they are the strength and pillar of existing blended learning schemes; these actually are the pride of the University.

$\mathrm{Q}_{3}$ has eight attributes that should be efficiently remarked for the next operations: $\mathrm{X}_{63}$ (sufficient), $\mathrm{X}_{62}$ (interactive), $\mathrm{Y}_{61}$ (relevance), $\mathrm{X}_{42}$ (attentive), $\mathrm{X}_{22}$ (multi-way), $\mathrm{X}_{12}$ (comprehensive), $\mathrm{X}_{41}$ (discipline) and $\mathrm{S}_{3}$ (updated). This quadrant is an indication of both satisfaction and the degree of its importance is in a low category. The University should classify these eight points as the next focus after concentrating on the crucial spots found in $\mathrm{Q}_{1}$ and $\mathrm{Q}_{2}$. Any attribute falls into $\mathrm{Q}_{3}$ is not so important and poses no risk in terms of student satisfaction in Universitas Terbuka context.

$\mathrm{Q}_{4}$ has three attributes that in terms of its exigency is relatively similar to $\mathrm{Q}_{3}$, they are: $\mathrm{S}_{1}$ (systematic), $\mathrm{X}_{11}$ (more independent), and $\mathrm{S}_{5}$ (flexible). $\mathrm{Q}_{4}$ indicates that academic service provided is considered much less important but some students experienced them as high in satisfaction. Here, attention to these three lesser critical aspects can also be less focused. This implies that the University can save costs by redirecting efforts to take up vital attributes in $Q_{1}$, by first moving them to $Q_{2}$ and at the same time maintaining essential attributes fall in $\mathrm{Q}_{2}$ resolutely.

\section{The loading factor analysis}

Having arranged attributes and dimensions related to proper quadrants in the IPA-CSI chart, we are now turning to associate the loading factors analysis of the operational framework. This is to comment on the power of relations each variable involved one another (as an integrated model) under SEM approach to work out the end results. Figure 3 quantitatively displayed five crucial consequences need to be prudently noticed, as follows.

The first is related to the four out of six main independent variables that directly influenced satisfaction (S). They are: management $\left(X_{4}=0.36\right)$, interactivity $\left(X_{2}=0.25\right)$, instructor $\left(\mathrm{X}_{3}=0.22\right)$ and instruction $\left(\mathrm{X}_{1}=0.21\right)$ respectively. This implies that the qualitative upshots were imperfectly validated by the quantitative approach. They are slightly different both in terms of endorsed variables through quantitative procedure and in the order or rank of the variables themselves. Qualitatively, the independent variables factually consisted orderly of instruction, interactivity, instructor, management, technology and OER-wise. 
Despite the qualitative upshots here were imperfectly approved along the processes, but quantitative end objectively placed management factor as the main influence to satisfaction. It implies that from management outlook (with discipline, consistency and attentiveness attributes in conjunction with blended learning satisfaction), it should be taken into account the following considerations. The University for example is strongly suggested to initiate collaboration with well-established and reputable higher education providers that has shown great efforts in digital learning space. It will provide programs with access to a wider range of resources at the disposal of the university as well as eliminating the need to build them from the scratch. Moreover, this will provide the opportunity in assuring program quality while minimising costs.

By practicing this arrangement, there are strategic advantages of this type of collaboration, such as access to high-standard learning content, physical resources, IT infrastructures, knowledge capital around leading best practices, research and content experts. In addition, access to technical support, expert in pedagogy and teaching, affiliation with recognised brand name when seeking funding and/or partners, and the power to provide learners with recognised accreditation for program completion are more open and possible (Accenture, 2015, p.42). These are the way how to assure discipline, consistency and attentiveness that might be prudently controlled as the main indicators of management factor, again, with respect to blended learning satisfaction.

The second is related to the order of dimensions. In management $\left(\mathrm{X}_{4}\right)$ : discipline $\left(X_{41}=0.98\right)$ and then followed by consistent $\left(X_{43}=0.96\right)$ and attentive $\left(X_{42}=0.89\right)$. In interactivity $\left(\mathrm{X}_{2}\right)$ : multi-way $\left(\mathrm{X}_{21}=0.93\right)$ and then followed by focus/alert $\left(\mathrm{X}_{21}=0.88\right)$ and prompt $\left(\mathrm{X}_{23}=0.75\right)$. In instructor $\left(\mathrm{X}_{3}\right)$ : open $\left(\mathrm{X}_{33}=0.96\right)$ and then followed by encouraging $\left(\mathrm{X}_{32}=0.95\right)$ and available $\left(\mathrm{X}_{31}=0.79\right)$. In instruction $\left(\mathrm{X}_{1}\right)$ : more independent $\left(\mathrm{X}_{11}=0.90\right)$ and then followed by both comprehensive and ready for exam $\left(\mathrm{X}_{12}=\mathrm{X}_{13}=0.89\right)$. Now the question is: How to assure interactivity, instructor and instruction in blended learning scheme? First, how we position the scheme: customise or industrialise. By choosing this option, we will be able to follow the next consequence. In other words, it needs to follow how to design ways of improving content, overcoming barriers to accessibility, validating learning processes and encouraging learners to be more active. These efforts will altogether provide opportunities effectively to confirming satisfaction level in blended learning systems behold by users or students.

The third finding is that respondents put the rank of satisfaction (S) from the provision of blended learning perspectives with respect to: updated $\left(\mathrm{S}_{3}=0.80\right)$, systematic $\left(S_{1}=0.79\right)$, enjoyable $\left(S_{4}=0.75\right)$, helpful $\left(S_{2}=0.73\right)$ and flexible $\left(S_{5}=0.69\right)$. In this case, the order of dimensions in satisfaction toward blended learning scheme is also altered. Initially, it was considered that satisfaction would be primarily based upon how systematic the scheme is, but factually students put how updated the blended learning provided was much more crucial. This upshot is supposedly comparable with Poon (2013b), whereby students found the integration of overall structure of module (lecture, workshop, seminar and the use of virtual learning environment) will enhance their learning experience. Moreover, students found that if the structure of module was practical and had a good balance of theory and practice will make the concepts easier to understand. It is relevant then to suggest changes, if possible, focusing on greater use of technology during the module delivery and making it more merged. It implies that a more interactive delivery style should be adopted. This would provide support to students for learning and developing their professional skills. Besides, an online discussion platform should also be developed to facilitate students' peer support. 
The fourth is in association with the power of relations amongst satisfaction (S) and enhance learning $\left(\mathrm{Y}_{1}\right)$, competence $\left(\mathrm{Y}_{2}\right)$, motivation $\left(\mathrm{Y}_{3}\right)$, retention $\left(\mathrm{Y}_{4}\right)$ and value $\left(\mathrm{Y}_{5}\right)$. Figure 3 clearly confirmed that satisfaction has significant and direct effects on students: retention $\left(\mathrm{Y}_{4}=0.65\right)$, enhance learning $\left(\mathrm{Y}_{1}=0.56\right)$, value $\left(\mathrm{Y}_{5}=0.49\right)$, motivation $\left(\mathrm{Y}_{3}=0.43\right)$ and competence $\left(\mathrm{Y}_{2}=0.42\right)$ successively. Originally, it was hypothesised that the more students satisfied with the scheme, then it will enhance their learning capacity and spirit. In fact, respondents believe that their satisfaction are much more related to their retention. This implies that they are more capable of explaining what they have been studied and at the same time they still able remembering and answering questions while in turn doing their final exams. Partially, this result is supported by the fact that shifting the presentation of course from a traditional approach to a blended approach, while keeping the intellectual content and course evaluation consistent, will lead to an increase in student learning as evaluated by exam performance and overall course point totals (Kiviniemi, 2014). At the same time, student feedback about the approach was quite positive and they are impressively preferred blended approach to a more traditional course structure. Therefore, well-executed blended approach may have convincing aptitude to enhance student performance academically.

The fifth is on the position of dimensions in retention $\left(\mathrm{Y}_{4}\right)$ : explicable $\left(\mathrm{Y}_{41}=0.84\right)$ and memorable $\left(\mathrm{Y}_{42}=0.74\right)$; in learning $\left(\mathrm{Y}_{1}\right)$ : supplementary $\left(\mathrm{Y}_{11}=0.97\right)$ and reinforcement $\left(\mathrm{Y}_{21}=0.81\right)$; in value $\left(\mathrm{Y}_{5}\right)$ : beneficial $\left(\mathrm{Y}_{52}=0.77\right)$ and applicable $\left(\mathrm{Y}_{51}=0.74\right)$; in motivation $\left(\mathrm{Y}_{3}\right)$ : enthusiastic $\left(\mathrm{Y}_{32}=0.87\right)$ and inquisitive $\left(\mathrm{Y}_{31}=0.80\right)$; and in competence $\left(\mathrm{Y}_{2}\right)$ : knowledge $\left(\mathrm{Y}_{21}=0.88\right)$ and skill $\left(\mathrm{Y}_{22}=0.82\right)$. In general, the results of quantitative series gained here are slight distinct from what was formerly established under qualitative framework. Fortunately, it still follows the initial variables established as cited from Smaldino et al. (2008); they only differ in terms of the order.

Prior to discussing quantitative and qualitative results, it is worth to observe the goodness of fit of the framework. The analysis showed that in general they can be categorised in "acceptable" classification despite the RMSEA (Root Mean Square Error of Approximation) is in a "poor fit" category (Table 3).

Table 3 Goodness of fit of the tested framework

\begin{tabular}{lccl}
\hline Goodness of Fit & Cut-off Value & Results & Notes \\
\hline$R M R_{\text {Root Mean Square Residual }}$ & $<0,05$ or $<0,1$ & 0.10 & Good Fit \\
$R M S E A_{\text {Root Mean Square Error of Approximation }}$ & $<0.08$ & 0.10 & Poor Fit \\
GFI Goodness of Fit $_{\text {A }}$ & $>0.90$ & 0.94 & Good Fit \\
FFI $_{\text {Adjusted Goodness of Fit Index }}$ & $>0.90$ & 0.93 & Marginal Fit \\
$C F I_{\text {Comparative Fit Index }}$ & $>0.90$ & 0.94 & Good Fit \\
$N F I_{\text {Normed Fit Index }}$ & $>0.90$ & 0.93 & Good Fit \\
$N N F I_{\text {Non-Normed Fit Index }}$ & $>0.90$ & 0.94 & Good Fit \\
IFI $_{\text {Incremental Fit Index }}$ & $>0.90$ & 0.94 & Good Fit \\
RFI $_{\text {Relative Fit Index }}$ & $>0.90$ & 0.92 & Marginal Fit \\
\hline
\end{tabular}

There should be a specific attempt to see what was the real reason behind this imperfect output and why. Nonetheless, they are still reliable to be used as a point of reference to draw an inferential interpretation. 
Having collected and aggregated outcomes accomplished under quantitative and qualitative sequence and then followed by expert judgement (by faculty members as management and academic), three major effects need to be prudently remarked. This is pertinent as the qualitative configuration were not entirely in concordance with the operational (quantitative) framework upshots. This implies that the qualitative upshots were slightly distinct with the suggested operational quantitative framework; it needs further assessment and interpretation.

\section{Critical remarks}

The first note is related to the conceptual and operational framework of the study (refer to Figure 1, Figure 2 and Figure 3; including Table 1). The second is on the IPA-CSI Chart (Figure 4). The third is on the methodology chosen (mixed methods: the exploratory design).

The first note is on the established framework. Quantitatively, management aspect was apprehended as the prime factor, then followed by interactivity, instructor and instruction related to the blended learning scheme satisfaction in Universitas Terbuka tradition; viewed by students under scholarship scheme. This result is largely consistent with the qualitative upshot. In other words, the four factors are also found from literatures, interviews and FGDs approaches despite the technology and OER-wise aspects were both excluded by the quantitative analysis. In terms of its order, however, selected experts preferred to express satisfaction in this context leads to enhance learning, competence, motivation, retention and value. This means that the quantitative end was imperfectly supported by the experts view. It appears a slight incongruity between quantitative and qualitative outcomes in terms of the order of dependent variables. The gap is lightly exist but fortunately it does not create a convincing contradictory. It rather gives us wider perspectives to be noted if comparable study is set in the near future.

The quantitative corollaries comparatively excluded technology and OER-wise from the main variables of the framework. Gazing at this evidence, it might implicitly indicate that students (here they are all under scholarships scheme) were much more concerned on management, interactivity, instructor and instruction rather than that of aspects on technology and OER-wise. An auxiliary explanation for this is due to most of the respondents are essentially familiar with information technology aspects and the internet as well as how to make used of them all. They are all selected and smart young students; their academic performance was also highly recognised (refer to Table 2).

The second note is on the IPA-CSI Chart produced. Referring to another effect related to the Chart (Figure 4), the qualitative inquiry completed are almost exclusively equivalent with the quantitative one. However, it was unanticipated that management consistency for example $\left(\mathrm{X}_{43}\right)$ fell in "Concentrate Here" or quadrant $\left(\mathrm{Q}_{1}\right)$. This means that there was still a problem acquiring good service from management side. All the same, most respondents stated that the first influential variable to satisfaction was management aspect; again, further and deeper inquiry underpinned this regard exist is certainly needed. It indicates that the University should pay attention to this spot. Respondents considered management consistency is critical but most of them found it was unsatisfied. Additionally, multi-way interaction and response to support students were also found in this quadrant This entails that the University should put this attribute as a top priority to be seriously tackled and by all means moved them to $\mathrm{Q}_{2}$ to meet student needs and expectations; these are also the concerns of the experts. 
The third note is on the methodology chosen. Looking up to the methodological perspectives, it appears that mixed method used in this study is generally suitable despite there was a slight difference related to the quantitative final results. However, they are categorised firmly limited in numbers or low in implications with respect to the conceptual and operational frameworks established in advance. The differences in terms of end results took place in the level of ranks; but, it is not in high intensity.

Besides, from methodological direction, the outcome gives durable bases that mixed method with the choice of exploratory design was suitable to assess satisfaction in blended learning system viewed by both the experts and students engaged in this inquiry in Universitas Terbuka context. Quantitatively, it is understandable that IPA-CSI approach was able to distinctively display what are things should be positioned within the top priority and should be controlled prudently $\left(\mathrm{Q}_{1}\right)$. The approach is proficient to classify things should be persistently maintained $\left(\mathrm{Q}_{2}\right)$ and at the same time what are things classified as the next priority and less focused, namely all attributes fall in $\mathrm{Q}_{3}$ and $\mathrm{Q}_{4}$ (Wong et al., 2012).

The IPA-CSI chart effects are also reinforced by the SEM output. By combining these upshots, it will direct the University for being able to formulate effective course of actions with respect to student expectation in blended learning provision. It is providential that qualitative inquiry was in line with the quantitative results. It is normal that most universities are constrained by noticeable supplies, namely 5M: Man, money, material, machine and method (Aisyah et al., 2016; Sembiring 2016). Pondering to these potential constraints, it is appropriate to formulate notions on how to effectively re-address the existing assets so that there are sufficient endeavors and related supports to mainly focus on dealing with and maintaining attributes in $\mathrm{Q}_{1}$ and $\mathrm{Q}_{2}$ respectively; as also indicated by Tileng et al. (2013).

In Universitas Terbuka context, this result is constructive with respect to reformulating things that should be put as a top priority to fulfil student expectation to satisfy their needs through the provision of effective blended learning system. Three aspects dropped into $\mathrm{Q}_{1}$ should be brilliantly controlled with high intent (they are: management consistency, prompt and fast interactivity and quick response to help student query). Additionally, nine aspects drop into $\mathrm{Q}_{2}$, such as enjoyable program, instructor openness, technologically friendly, technologically affordable, encouraging instructor to facilitate student ready and success for their exam, technologically reliable, focus on interactivity and instructor always available should be repetitively conserved as they are the pillar and pride of the University in assuring academic excellence. These things are also being the main concerns of the management to be noticed. Principally, aspects from $\mathrm{Q}_{1}$ can be moved onto $\mathrm{Q}_{2}$. If this took place, it will improve the number of students getting satisfied with provided services.

Referring to the first and second questions of the study stated earlier, it can be highlighted that most respondents as well as selected experts contended that the blended learning scheme offered and accessed by users (students under scholarship scheme in this regard) were in the right track with satisfied classification. This limited summary, to certain extent, was explained by the result from the final questions in the questionnaire that fulfilled by all respondents. In the end, respondents were asked a closing question. The question: overall, how would you rate blended learning offered by the University? Remarkably, the answer gave us conclusive credence that in the future Universitas Terbuka will be able to provide better quality blended learning so student are really 
competence and motivated to completing their study. The answer for this question: (1) Unsatisfied: $2.63 \%$; (2) Uncertain: $13.82 \%$; and (3) Satisfied: $83.55 \%$. It obviously implies less than $3 \%$ of respondents are dissatisfied.

By considering this positive highlight, according to resource persons as an expert for this study, students will clearly be having supportive experience in pursuing their degree through enjoyable learning atmosphere provided by the University through blended scheme. This implies that blended learning provided by the University is improved in one hand and positively will support student performance academically on the other hands. The management clearly accepted this fact by trying to always find good ways of making each essential and operative aspects of the scheme meets as many students expectation as possible. This fact might also be used as a reflection of reducing the pressure that is mounting on universities to transform especially the way to deliver on of the core activities, namely effective and enjoyable teaching and/or learning process.

\section{Concluding remarks}

The study quantitatively ascertains that satisfaction in blended learning leads to student retention, learning, value, motivation and competence. This upshot is relatively different but only in terms of the order as compared to the initial qualitative framework and expert views. Besides, satisfaction itself is orderly influenced by management, interactivity, instructor and instruction; there is a slight difference too as compared to the qualitative configuration. Readers are critically subjected to noticing this fact just in case of implementing comparable research based on this attempt. Under IPA-CSI procedures, three aspects should be cautiously taken into account, i.e., management consistency, multi-way interaction and quick response to handle student queries. These three aspects are generally crucial to be taken into account to everybody to assure satisfaction on the blended learning viewed from student stance.

Apart from that, according to Kintu (2017), it also relevant to observe satisfaction in blended learning scheme by considering students characteristics. Quantitative analysis results indicated that blended learning design features, such as technology quality, online tools and face-to-face support as well as student characteristics, attitudes and selfregulation for examples, predicted student satisfaction as an outcome. This implies that results designated that student characteristics and/or backgrounds including design features are substantial predictors for student achievements in blended learning setting. Moreover, the portion of face to face interaction and the ease of using the web environment are those two important aspects should be noted rather than that of learning styles (Akkoyunlu and Soylu, 2008). These last aspects should also be taken into account apart from what was disclosed under the results of this investigation. This is to anticipate and accommodate other potential variables and dimensions concerning blended learning issues with respect to provide quality and effective blended learning for users, primarily student in this regard.

Methodologically, it can be inferred that the qualitative framework is imperfectly approved by the quantitative ending. Further research is crucial, including the follow-up with all students as respondents (total students of the University is around 290,000). It should also explore satisfaction level beyond attributes included in the six independent variables assessed here. Another aspect that needs to be seriously considered to have better results on blended learning satisfaction, for examples, are the interactions in 
blended learning itself, the use of Learning Management Systems and its tools, learning performance as well as technology quality (Kintu and Zhu, 2016). By implementing such activity and by including those factors, it would set onward of more wide-ranging angles particularly on student competence, motivation, retention and the ability to apply knowledge and skills they obtained from their program from the University. This will grant the prospect to Universitas Terbuka to exterminate restrictions for the nations to gain more access to improve their qualification through quality education in higher level.

Given this interpretation is universally emblematical, ODeL stakeholders would be well-advised to consider the findings obtained here to deliver better academic services to students. For Universitas Terbuka, student persistence can be maintained through the provision of effective academic excellence through quality blended learning scheme (Sembiring, 2015; 2016). This will direct the University to reassure its respectable mission of making higher education open to all to protect the nation through flexible quality education. The University is dignified to reach the vision of becoming a world quality institution in preparing world quality graduates (Universitas Terbuka, 2014).

\section{References}

Accenture (2015) How to Design and Scale Digital and Blended Learning Programs to Improve Employment and Entrepreneurship Outcomes. Available online at: https://www.accent ure.com/t20170203T040028Z_w/us-en/_acnmedia/PDF-5/Accenture-Digital-LearningReport-and-How-To-Guide_Full.pdf (accessed on 4 November 2017).

Aisyah, S., Ibrahim, N., Purwodadi, T., Sopandi, A.T. and Sembiring, M.G. (2016) 'Exploring student satisfaction with blended learning in Universitas Terbuka', Paper presented at the $30^{\text {th }}$ Asian Association of Open Universities Annual Conference, 26-29 October, Manila, the Philippines.

Akkoyunlu, B. and Soylu, M.Y. (2008) 'A study of student's perceptions in a blended learning environment based on different learning styles', Educational Technology and Society, Vol. 11, No. 1, pp.183-193.

Bates, A.W. (2015) Teaching in a Digital Age: Guidelines for designing Teaching and Learning. Available online at: https://www.tonybates.ca/teaching-in-a-digital-age/

Bird, D.K. (2009) 'The use of questionnaires for acquiring information on public perception of natural hazard and risk mitigation - a review of current knowledge and practice', Natural Hazards and Earth System Sciences, Vol. 9, pp.1307-1325. Available online at: http://www.nat.hazards-earth-syst-sci.net/9/1307/2009 (accessed on 9 March 2016).

Cochran, W.G. (1977) Sampling Techniques, 3rd ed., John Wiley and Sons, New York.

Creswell, J.W. and Clark, V.L.P. (2011) Designing and Conducting Mixed Methods Research, 2nd ed., Sage Publication, Inc., Los Angles.

Fowler, F.J., Jr. (2014) Survey Research Methods, 5th ed., SAGE, Los Angeles.

Garisson, D.R. and Kanuka, H. (2004) 'Blended learning: uncovering its transformative potential in higher education', The Internet and Higher Education, Vol. 7, No. 2, pp.95-105.

Hair, Jr., J.F., Black, W.C., Babin, B.J. and Anderson, R.E. (2009) Multivariate Data Analysis with Readings, 7th ed., Prentice Hall Incorporated, New Jersey, NJ.

Ibrahim, I., Sembiring, M.G. and Sapriati, A. (2016) 'Investigating satisfaction with blended learning in Universitas Terbuka framework', Paper presented at the Educational Technology World Conference, 31 July - 3 August 2016, Bali, Indonesia. Available online at: http://seminars.unj.ac.id/etwc.

Kanwar, A., Kodhandaraman, B. and Umar, A. (2010) 'Toward sustainable open educational resources: a perspective from the Global South', The American Journal of Distance Education, Vol. 24, No. 2, pp.65-80. 
Kennedy, J. and Newcombe, E (2011) 'Adopting a blended learning approach: challenges encountered and lessons learned in an action research study', Journal of Asynchronous Learning Networks, Vol. 15, No. 1, pp.45-57.

Kintu, M.J. and Zhu, C. (2016) 'Student characteristics and learning outcomes in a blended learning environment intervention in a Ugandan University', Electronic Journal of eLearning, Vol. 14 No. 3, pp.181-195. Available online at: https://eric.ed.gov/?id=EJ1107126 (accessed on 3 November 2017).

Kitcharoen, K. (2004) 'The IPA of Servqual in administrative departments of private universities in Thailand', ABAC Journal, Vol. 24, No. 2, pp.20-46.

Kiviniemi, M.T. (2014) 'Effects of a blended learning approach on student outcomes in a graduatelevel public health course', BioMed Center Medical Education, Vol. 14, pp.1-7. DOI: 10.1186/1472-6920-14-47.

Liyanagunawardena, T.R., Adams, A.A., Rassool, N. and Williams, S.A. (2014) 'Blended learning in distance education: Sri Lankan perspective', International Journal of Education and Development Using Information and Communication Technology, Vol. 10, No. 1, pp.55-69.

Moore, M.G. and Kearsly, G. (2012) Distance Education: A System View of Online Learning, 3rd ed., Wadsworth Cengage Learning, Belmont, CA, USA.

Naaj, M.A., Nachouki, M. and Ankit, A. (2012) 'Evaluating student satisfaction with blended learning in a gender-segregated environment', Journal of Information Technology Education Research, Vol. 11, pp.187-200.

Osguthorpe, T.R. and Graham, R.C. (2003) 'Blended learning environments', Quarterly Review of Distance Education, Vol. 4, No. 3, pp.227-233.

Poon, J. (2013a) 'Blended learning: an institutional approach for enhancing students' learning experience', MERLOT Journal of Online Learning \& Teaching, Vol. 9, No. 2, pp.1-14.

Poon, J. (2013b) 'An examination of a blended learning approach in the teaching of economics to property and construction students', Property Management, Vol. 31, No. 1, pp.39-54. Available online at: https://doi.org/10.1108/02637471311295405.

Sembiring, M.G. (2015) 'Validating student satisfaction related to persistence, academic performance, retention and career advancement within ODL perspectives', Open Praxis, Vol. 7, No. 4, pp.311-323.

Sembiring, M.G. (2016) 'OER impact study perceived by faculty within ODL framework', Emerald Asian Association of Open Universities Journal, Vol. 11, No. 1, pp.78-89. DOI: http://dx.doi.org/10.1108/AAOUJ-07-2016-0021.

Silva, F. and Fernandes, O. (2010) 'Using importance-performance analysis in evaluating of higher education: a case study', International Conference on Education and Management Technology, IEEE, pp.121-123.

Smaldino, S.E., Lowther, D.L. and Russel, J.D. (2008) Instructional Technology and Media for Learning, Pearson Merril Prentice Hall, New Jersey.

Tileng, M.Y., Wiranto, H.U. and Latuperissa, R. (2013) 'Analysis of service quality using Servqual method and IPA in Population Department, Tomohon City, South Sulawesi', International Journal of Computer Applications, Vol. 70, No. 19, pp.23-30.

Universitas Terbuka (2014) Strategic and Operational Planning of Universitas Terbuka 20142021, Universitas Terbuka, Tangerang Selatan, Indonesia.

Universitas Terbuka (2016) Annual Report of the Rector Office, Universitas Terbuka, Tangerang Selatan, Indonesia.

Wijayanto, S.H. (2008) Structural Equation Modeling - Lisrel 8.80, Graha Ilmu, Yogyakarta, Indonesia.

Wong, M.S., Hideki, N. and George, P. (2011) 'The use of importance-performance analysis in evaluating Japan's e-government services', Journal of Theoretical and Applied Electronic Commerce Research, Vol. 6, No. 2, pp.17-30. 


\section{Appendix: The Questionnaire}

\section{QUESTIONNAIRE}

NO:

.$/ 600$

Dear Universitas Terbuka Students under Scholarship Scheme throughout Indonesia. I am asking your contribution to complete this questionnaire with respect to the need of improving our blended learning scheme to satisfy students need in the future.

It was aimed at predicting as well as validating student satisfaction on our blended learning scheme viewed by students from instruction, interactivity, instructor, management, technology and open educational resources (OER) perspectives. It was also of interests to foresee how satisfaction itself related to enhancing student learning, competence, motivation, retention and value.

The result of this process will be analysed and finally utilised as a positive inputs to improve current blended learning operated so that it satisfies students need and expectation with respect to their academic achievement. At the end, it is expected that all students will be able to complete their study with excellent grade and more importantly they will finish their study on schedule.

Prior to answering related questions on the questionnaire, please complete information concerning your personal detail by marking $\mathbf{X}$ in each relevant box [ ] accordingly.

\begin{tabular}{|c|c|c|c|c|}
\hline Faculty & [ ] Economics & $\begin{array}{l}\text { [] Social and } \\
\text { Political Science }\end{array}$ & \multicolumn{2}{|c|}{$\begin{array}{l}\text { [ ] Mathematics and Natural } \\
\text { Sciences }\end{array}$} \\
\hline Study Program & Please state it... & & & \\
\hline Regional Office & Please state it ... & & & \\
\hline \multirow[t]{2}{*}{ GPA for 2016} & [ ] $0.00-0.99$ & [ ] $1.00-1.49$ & [ ] $1.50-1.99$ & [ ] 2.00-2.49 \\
\hline & [ ] $2.50-2.99$ & [ ] $3.00-3.49$ & [ ] $3.50-3.99$ & [ ] 4.00 \\
\hline Age (Year) & {[]$<20$} & [ ] 21-23 & [ ] 24-26 & {[]$>27$} \\
\hline Length of Study & {[]$<2$ years } & [] 3 years & [ ] 4 years & [] $>5$ years \\
\hline Marital Status & [] No & [] Yes & Children & [] Yes [] No \\
\hline Job & [] No & [] Yes & [ ] Part time & \\
\hline Gender & [ ] Female & [] Male & & \\
\hline
\end{tabular}

Again, please feel free to seriously fulfil of some questions as provided in the next page. Thank you for your great contribution and all the best for your study at Universitas Terbuka. 


\begin{tabular}{|c|c|c|c|c|c|c|c|c|c|c|c|}
\hline \multirow{2}{*}{\multicolumn{2}{|c|}{$\begin{array}{l}\text { Please indicate your satisfaction level and } \\
\text { importance degree on the several } \\
\text { questions/statements based on your experience } \\
\text { related to the following aspects by marking } \\
\text { with } \mathbf{X} \text { in the relevant box. }\end{array}$}} & \multirow{2}{*}{\multicolumn{5}{|c|}{\begin{tabular}{|l|} 
SATISFACTION \\
5: Absolutely satisfied \\
4: Very satisfied \\
3: Satisfied \\
2: Not Satisfied \\
1: Completely \\
$\quad$ unsatisfied \\
\end{tabular}}} & \multirow{2}{*}{\multicolumn{5}{|c|}{$\begin{array}{l}\text { IMPORTANCE } \\
\text { 5: Absolutely important } \\
\text { 4: Very important } \\
\text { 3: Important } \\
\text { 2: Not important } \\
\text { 1: Completely } \\
\quad \text { unimportant }\end{array}$}} \\
\hline & & & & & & & & & & & \\
\hline No. & $\begin{array}{l}\text { QUESTIONS ON THE SATISFACTION } \\
\text { LEVEL AND IMPORTANCE DEGREE }\end{array}$ & 1 & 2 & 3 & 4 & 5 & 1 & 2 & 3 & 4 & 5 \\
\hline 1 & $\begin{array}{l}\text { Self-sufficiency from the blended } \\
\text { learning scheme (BLS) }\end{array}$ & $\square$ & $\square$ & $\square$ & $\square$ & $\square$ & $\bullet$ & • & $\bullet$ & $\bullet$ & • \\
\hline 2 & $\begin{array}{l}\text { Ability to comprehend materials } \\
\text { comprehensively }\end{array}$ & $\square$ & $\square$ & $\square$ & $\square$ & $\square$ & $\bullet$ & • & $\bullet$ & $\bullet$ & • \\
\hline 3 & Readiness for semester final exam & $\square$ & $\square$ & $\square$ & $\square$ & $\square$ & $\cdot$ & $\cdot$ & $\cdot$ & $\cdot$ & $\cdot$ \\
\hline 4 & The focus of material being taken & $\square$ & $\square$ & $\square$ & $\square$ & $\square$ & $\cdot$ & $\cdot$ & $\cdot$ & $\cdot$ & $\cdot$ \\
\hline 5 & $\begin{array}{l}\text { Multi-way communication on academic } \\
\text { aspect }\end{array}$ & $\square$ & $\square$ & $\square$ & $\square$ & $\square$ & $\bullet$ & • & • & $\bullet$ & • \\
\hline 6 & $\begin{array}{l}\text { Quick response in handling academic } \\
\text { queries }\end{array}$ & $\square$ & $\square$ & $\square$ & $\square$ & $\square$ & $\bullet$ & • & $\bullet$ & $\bullet$ & • \\
\hline 7 & Tutor availability & $\square$ & $\square$ & $\square$ & $\square$ & $\square$ & $\bullet$ & $\cdot$ & $\bullet$ & $\cdot$ & $\cdot$ \\
\hline 8 & $\begin{array}{l}\text { Tutor capability in motivating students to } \\
\text { study }\end{array}$ & $\square$ & $\square$ & $\square$ & $\square$ & $\square$ & $\bullet$ & • & • & $\bullet$ & - \\
\hline 9 & $\begin{array}{l}\text { Openness of tutor receiving feedback } \\
\text { from student }\end{array}$ & $\square$ & $\square$ & $\square$ & $\square$ & $\square$ & $\bullet$ & • & • & $\bullet$ & • \\
\hline 10 & Consistency in managing learning & $\square$ & $\square$ & $\square$ & $\square$ & $\square$ & $\cdot$ & - & $\cdot$ & $\bullet$ & $\cdot$ \\
\hline 11 & $\begin{array}{l}\text { Management response toward student } \\
\text { need }\end{array}$ & $\square$ & $\square$ & $\square$ & $\square$ & $\square$ & • & • & • & $\bullet$ & • \\
\hline 12 & $\begin{array}{l}\text { Management consistency supporting } \\
\text { student success }\end{array}$ & $\square$ & $\square$ & $\square$ & $\square$ & $\square$ & • & • & • & • & • \\
\hline 13 & $\begin{array}{l}\text { Access to use technological support for } \\
\text { academic purposes }\end{array}$ & $\square$ & $\square$ & $\square$ & $\square$ & $\square$ & • & • & • & • & • \\
\hline 14 & Sophistication of ICT media used & $\square$ & $\square$ & $\square$ & $\square$ & $\square$ & $\cdot$ & $\cdot$ & $\cdot$ & $\cdot$ & $\cdot$ \\
\hline 15 & $\begin{array}{l}\text { Simplicity on utilising available ICT } \\
\text { media }\end{array}$ & $\square$ & $\square$ & $\square$ & $\square$ & $\square$ & • & • & • & • & • \\
\hline 16 & $\begin{array}{l}\text { The optimal use of open educational } \\
\text { resources (OER) in BLS }\end{array}$ & $\square$ & $\square$ & $\square$ & $\square$ & $\square$ & • & • & • & • & • \\
\hline 17 & $\begin{array}{l}\text { Interactivity on the adoption of OER into } \\
\text { BLS }\end{array}$ & $\square$ & $\square$ & $\square$ & $\square$ & $\square$ & • & • & • & • & • \\
\hline 18 & Sufficiency of OER adoption in the BLS & $\square$ & $\square$ & $\square$ & $\square$ & $\square$ & $\cdot$ & $\cdot$ & $\cdot$ & $\bullet$ & $\cdot$ \\
\hline 19 & $\begin{array}{l}\text { The scheme of academic service on the } \\
\text { BLS }\end{array}$ & $\square$ & $\square$ & $\square$ & $\square$ & $\square$ & • & • & • & $\bullet$ & • \\
\hline 20 & $\begin{array}{l}\text { BLS in preparing students mastering } \\
\text { material for final exams }\end{array}$ & $\square$ & $\square$ & $\square$ & $\square$ & $\square$ & • & • & • & $\bullet$ & $\cdot$ \\
\hline 21 & $\begin{array}{l}\text { Renewing instructional mode of delivery } \\
\text { of learning materials }\end{array}$ & $\square$ & $\square$ & $\square$ & $\square$ & $\square$ & $\bullet$ & • & • & $\bullet$ & • \\
\hline 22 & $\begin{array}{l}\text { Reassurance use of all provided academic } \\
\text { services }\end{array}$ & $\square$ & $\square$ & $\square$ & $\square$ & $\square$ & $\bullet$ & • & • & $\bullet$ & • \\
\hline
\end{tabular}




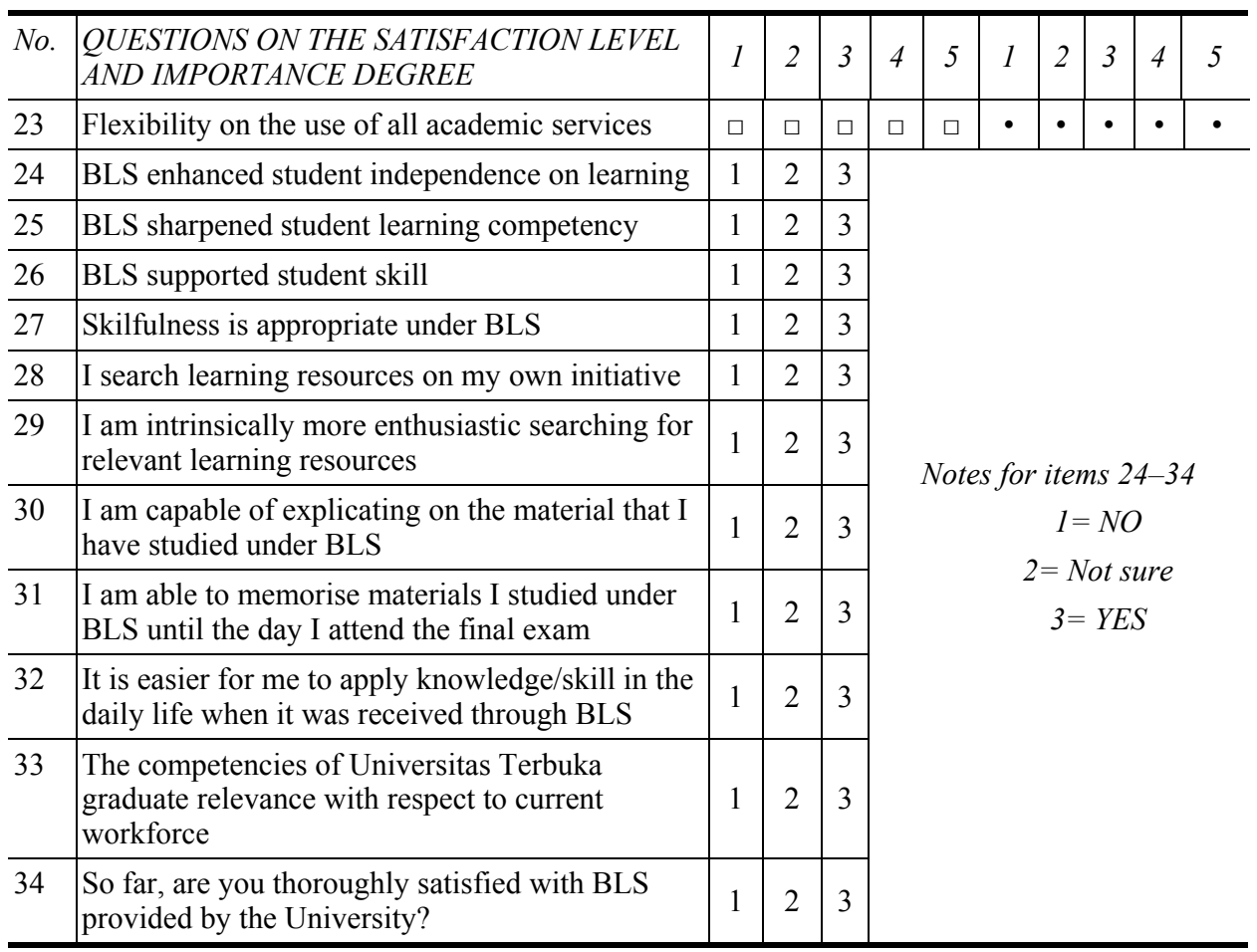

Once again, thank you and all the best for your future career. Think big. Start small. Do it now. Up to the edge. Never give up. The Nations are waiting for your contribution to make this country, Indonesia, GREAT (April 2017). 